\title{
ABBREVIATIONS AND REFERENCES
}

Abbreviations of Greek and Roman authors and their works, journals, lexica, and encyclopedias are those found in Liddell and Scott's GreekEnglish Lexicon; P. G. W. Glare, ed., Oxford Latin Dictionary; L'Année Philologique; and those in standard use (e.g., LSJ, RE, Roscher, etc.). In addition to these I make special note of the following abbreviations:

TEXTS, COMMENTARIES, AND INDICES OF THE ARGONAUTICA

Ardizzoni

Campbell

Campbell (Index)

Fränkel (OCT)

Fränkel

Hunter

Livrea

Mooney

Vian
A. Ardizzoni, Le Argonautiche libro I (Rome 1967)

M. Campbell, Echoes and Imitations of Early Epic in Apollonius Rhodius, Mnemosyne Supplement 72 (Leiden 1981)

M. Campbell, Index Verborum in Apollonium Rhodium (Hildesheim 1983)

H. Fränkel, Apollonii Rhodii Argonautica (Oxford 1961)

H. Fränkel, Noten zu den Argonautika des Apollonios (Munich 1968)

R. L. Hunter, Apollonius of Rhodes Argonautica Book III (Cambridge 1989)

E. Livrea, Apollonii Rhodii Argonauticon Liber IV (Florence 1973)

G. W. Mooney, The Argonautica of Apollonius Rhodius (reprint: Amsterdam 1987)

F. Vian, Apollonios de Rhodes Argonautiques chants I-II (Paris 1974) 
xvi

Vian (2)

Vian (3)

Wendel

F. Vian, Apollonios de Rhodes Argonautiques chant III (Paris 1980)

F. Vian, Apollonios de Rhodes Argonautiques chant IV (Paris 1981)

C. Wendel, Scholia in Apollonium Rhodium Vetera (Berlin 1935)

OTHER TEXTS, COMMENTARIES, INDICES, AND LEXICA
Bond
Davies
G. W. Bond, Euripides: Hypsipyle (Oxford 1963)
Dunbar
M. Davies, Epicorum Gracorum Fragmenta (Gött- ingen 1988)
FGrHist
H. Dunbar, A Complete Concordance to the Odys- sey of Homer, rev. B. Marzullo (reprint: Hil- desheim 1971)
FGrHist F. Jacoby, Die Fragmente der griechischen His- toriker (Berlin 1923-)
FHG C. Müller and T. Müller, Fragmenta Historicorum Gracorum (Paris 1841-70)
GGM
C. Müller, Geographici Graci Minores (Paris, 1855-61)
$L I M C$
Lexicon Iconographicum Mythologia Classica ( $\mathrm{Zu}-$ rich 1981-)
Linnenkugel
A. Linnenkugel, De Lucillo Tarrheo Epigramma- tum Poeta, Grammatico, Rhetore (Paderborn 1926)

$\mathrm{M} \& W$

R. Merkelbach and M. L. West, Fragmenta Hesiodea (Oxford 1967)

Pf.

R. Pfeiffer, Callimachus, vols. 1 and 2 (Oxford 1949-53)

$P M G$

D. L. Page, Poeta Melici Graci (Oxford 1962)

Powell

J. U. Powell, Collectanea Alexandrina (Oxford 1925)

Prendergast

G. L. Prendergast, A Complete Concordance of the Iliad of Homer, rev. B. Marzullo (reprint: Hildesheim 1962)

Radt

S. Radt, Tragicorum Gracorum Fragmenta (TrGF), vols. 3 (Æschylus) and 4 (Sophocles) (Göttingen 1985,1977 , respectively) 
SH

Snell

$T G L$

$T L G$

Wyss
H. Lloyd-Jones and P. Parsons, Supplementum Hellenisticum, Texte und Kommentare Band 11 (Berlin 1983)

B. Snell and H. Mæhler, Pindari Carmina cum Fragmentis, 2 vols. (Leipzig: vol. $11984^{7}$, vol. $21975^{4}$ )

Thesaurus Grace Lingua, ed. B. Hase, G. Dindorf, and L. Dindorf (Paris 1831-65)

Thesaurus Lingua Graca (University of California, Irvine, 1987), read on the Packard Ibycus System

B. Wyss, Antimachi Colophonii Reliquia (Berlin 1936)

\section{SPECIAL STUDIES}

I refer to the following studies in abbreviated form; all others will be cited in full in the notes:
Beye
C. R. Beye, Epic and Romance in the Argonautica of Apollonius (Carbondale 1982)
Blumberg
K.W. Blumberg, "Untersuchungen zur epischen Tech- nik des Apollonios von Rhodos" (diss. Leipzig 1931)

Collins

J. F. Collins, "Studies in Book 1 of the Argonautica of Apollonius Rhodius" (diss. Columbia 1967)

Delage

E. Delage, La géographie dans les Argonautiques d'Apollonios de Rhodes (Paris 1930)

Giangrande

G. Giangrande, $Z u$ Sprachgebrauch Technik und Text des Apollonios Rhodios (Amsterdam 1973)

Händel

P. Händel, Beobachtungen zur epischen Technik des Apollonios Rhodios (Munich 1954)

Hunter (2) R. L. Hunter, "Short on Heroics': Jason in the Argonautica," CQ $3^{8}$ (1988) 436-53

Hurst

A. Hurst, Apollonius de Rhodes: Manière et cohérence (Bern 1967)

Knorr

E. Knorr, De Apollonii Rhodii Argonauticorum Fontibus Quœstiones Selecta (Leipzig 1902)

Lawall Anti-hero," YClS 19 (1966) 121-69 
xviii

Levin

D. N. Levin, Apollonius' Argonautica Re-examined, I: The Neglected First and Second Books, Mnemosyne Supplement 13 (Leiden 1971)

\section{SIGLA}

An equivalence symbol $(\approx)$ signifies that the word or phrase referred to on the left is similar or identical to that on the right. A word or phrase underlined once signifies an imitation of a word or phrase that occurs in a passage discussed immediately afterwards, where, if quoted, it is also underlined once. A word or phrase underlined twice signifies an imitation of a word or phrase that occurs in a second passage discussed immediately afterwards, where, if quoted, it is also underlined twice. A word or phrase underlined with a dotted line signifies a freer adaptation of a word or phrase that occurs in the passage discussed immediately afterwards, where it is also underlined with a dotted line. 